\title{
Epidemi obesitas dan dampaknya terhadap status kesehatan masyarakat serta sosial ekonomi bangsa
}

\author{
Masrul \\ Bagian Ilmu Gizi, Fakultas Kedokteran, Universitas Andalas \\ Korespondensi: Masrul, email: masrul@med.unand.ac.id
}

\begin{abstract}
Abstrak
Obesitas merupakan penyakit kronis dan multi faktorial dan juga disebut penyakit inflamasi kronik yang ditandai dengan peningkatan total lemak tubuh. Distribusi kejadian obesitas berhubungan dengan faktor jenis kelamin, usia, tingkat pendidikan, dan status ekonomi. Tujuan: Untuk memaparkan epidemi obesitas dan dampaknya terhadap status kesehatan masyarakat dan sosial ekonomi. Metode: Berdasarkan studi kepustakaan yang berhubungan dengan epidemi obesitas dan dampak obesitas. Hasil: Faktor risiko dasar terjadinya obesitas yaitu faktor peningkatan asupan, faktor metabolik, penggunaan kalori dan gen. Obesitas terbagi menjadi dua tipe yaitu obesitas sentral dan obesitas periferal. Dampak obesitas terhadap kesehatan masyarakat meliputi percepatan proses penuaan, gangguan kecerdasan, resistensi insulin, kanker, osteoatritis, kolelithiasis, dan kematian pada usia muda. Selain itu, obesitas juga berdampak pada sosial ekonomi seperti menurunnya kualitas kehidupan penderita, menurunnya produktivitas individu dan negara, tingginya biaya kesehatan negara, dan tingginya biaya yang dikeluarkan individu ketika sakit. Simpulan: Dibutuhkan pengendalian dan penanganan epidemi obesitas dengan pendekatan dalam aspek sosial, biologi, teknologi, dan ekonomi. Perubahan gaya hidup lebih ditekankan pada modifikasi perilaku makanan dan aktivitas fisik.
\end{abstract}

Kata kunci: obesitas; kesehatan masyarakat; sosial ekonomi

\begin{abstract}
Obesity is a chronic and multifactorial disease and is also called a chronic inflammatory disease characterized by an increase in total body fat. Distribution of the incidence of obesity is related to factors of gender, age, education level, and economic status. Objective: To describe the obesity epidemic and its impact on public health and socio-economic status. Method: Based on literature studies related to the obesity epidemic and the impact of obesity. Results: The basic risk factors for obesity are factors that increase intake, metabolic factors, calorie use, and genes. Obesity is divided into two types, namely central obesity and peripheral obesity. The impact of obesity on public health includes accelerating the aging process, intelligence disorders, insulin resistance, cancer, osteoarthritis, cholelithiasis, and death at a young age. In addition, obesity also has an impact on socioeconomic conditions such as decreasing the quality of life of patients, decreasing the productivity of individuals and countries, the high health costs of the country, and the high costs incurred by individuals when sick. Conclusions: It is necessary to control and handle the obesity epidemic with approaches in social, biological, technological and economic aspects. Lifestyle changes are more emphasized in the modification of food behaviour and physical activity.
\end{abstract}

Keywords: obesity; public health; social economics 


\section{PENDAHULUAN}

Tujuan kemerdekaan yang ingin dicapai oleh rakyat Indonesia pada awal kemerdekaan adalah untuk mencerdaskan kehidupan bangsa dan mencapai kesejahteraan umum. Untuk mencapai kecerdasan suatu bangsa ditentukan oleh berbagai faktor. Faktor dasar adalah tingkat dan kualitas pendidikan, kondisi status gizi, dan status kesehatan masyarakat. Tingkat kesejahteraan suatu bangsa mempunyai dimensi yang luas. Salah satunya adalah dicapainya derajat kesehatan dan status gizi yang optimal serta terbebas dari berbagai penyakit.

Untuk itu, berbagai indikator dikembangkan oleh badan-badan dunia seperti WHO, UNDP, Bank Dunia yaitu mengukur tingkat pembangunan sumber daya manusia suatu Negara yang dikenal dengan Human Development Index (HDI) yang di Indonesia disebut IPM. Pada tahun 2016 rangking HDI kita berada pada peringkat 113 dari 188 negara di dunia (UNDP 2016). ${ }^{1}$ Salah satu indikator dalam IPM ini adalah status gizi masyarakat.

Saat ini Indonesia masih sedang berada dalam era transisi epidemiologi gizi, dimana angka stunting (pendek dibanding usia) pada anak bawah lima tahun (BALITA) sebesar 37,2\% dan wasting 18,5\%, sedangkan gizi lebih sudah mencapai $11,9 \% .^{2}$ Sehingga saat transisi ini, Indonesia mengalami beban ganda dengan berbagai implikasinya terhadap derajat kesehatan masyarakat.

Kelebihan gizi pada Balita akan berdampak terus sampai dewasa. Kelebihan zat gizi ini dikenal dengan overweight dan obesitas. Obesitas jarang sekali dibicarakan sebelum abad ke-20 karena di waktu itu sebagian besar penduduk dunia masih menderita kekurangan gizi. Sehingga peningkatan berat badan penduduk masih merupakan pertanda peningkatan status kesehatan dan ekonomi suatu masyarakat. Baru sejak 25 tahun terakhir ini permasalahan obesitas dan dampaknya semakin meningkat dibahas dalam berbagai pertemuan ilmiah dan perencanaan kesehatan masyarakat di dunia.

Mekanisme dasar dari terjadinya kelebihan berat badan sampai obesitas adalah ketidakseimbangan masukan energi dan pengeluarannya. Penyebab dari ketidakseimbangan tersebut adalah mudahnya akses dan variasi jenis makanan yang kaya energi. Sebaliknya oleh kemajuan teknologi dan perubahan gaya hidup terjadi penurunan pengeluaran energi dari 1,69 kkal/menit/KgBB menjadi $1,57 \mathrm{kkal} / \mathrm{menit} / \mathrm{KgBB} .^{3}$

Dampak obesitas cukup luas terhadap berbagai penyakit kronik degeneratif seperti hipertensi, penyakit jantung koroner, stroke, kanker dan diabetes tipe 2 serta kelainan tulang. Akibat banyaknya penyakit yang bisa ditimbulkan oleh obesitas sehingga angka morbiditas dan mortalitas penderita obesitas cukup tinggi. Sehingga obesitas berdampak terhadap biaya kesehatan baik yang langsung maupun yang tidak langsung. Diperkirakan di negara maju obesitas menghabiskan 2$10 \%$ biaya kesehatan nasional masing- 
masing negara setiap tahun. Di negara berkembang bisa melebihi dari $10 \% .{ }^{4}$

Untuk itu diperlukan langkah pencegahan sedini mungkin. Apabila sudah terjadi kelebihan berat badan sejak anak-anak dan dewasa sudah terbentuk sel adiposa yang berfungsi untuk penyimpanan lemak. Sehingga tidak mudah menurunkannya bahkan mengeluarkan biaya pula untuk menurunkan. Di Amerika Serikat diperlukan biaya setiap tahun sebesar $5 \%$ dari biaya kesehatan nasional. Di samping biaya langsung ada pula biaya tidak langsung berupa kehilangan hari kerja, kematian pada usia muda, biaya asuransi yang tinggi, produktivitas yang tidak optimal. Karena besarnya dampak obesitas terhadap status kesehatan masyarakat baik berupa kesakitan, kecacatan dan kematian dini serta pengeluaran biaya kesehatan yang tinggi bagi keluarga dan Negara. Untuk itu persoalan obesitas dan berbagai penyakit yang menyertainya sudah merupakan permasalahan kesehatan yang mesti ditanggulangi secara komprehensif baik preventif, promotif dan kuratif.

Artikel ini bertujuan untuk memaparkan epidemi obesitas dan dampaknya terhadap status kesehatan masyarakat dan sosial ekonomi.

\section{METODE}

Artikel ini ditulis berdasarkan studi kepustakaan yang berhubungan dengan epidemi obesitas dan dampak obesitas terhadap status kesehatan masyarakat serta sosial ekonomi bangsa.

\section{HASIL DAN PEMBAHASAN}

\section{EPIDEMIOLOGI OBESITAS DI BERBAGAI NEGARA}

Di negara maju permasalahan kesehatan akibat obesitas saat ini melebihi masalah kesehatan akibat rokok dan alkohol. Beberapa ahli menyebutkan obesitas sudah suatu epidemi bahkan ada yang menyebutnya dengan pandemi.

Peningkatan prevalensi dari insiden obesitas di negara maju dan berkembang sudah terjadi sejak 25 tahun terakhir. Di Indonesia sejak Survei Kesehatan Rumah Tangga (SKRT) kedua sudah mulai ada data kelebihan berat badan dan obesitas ini sejak dilaksanakan Riset Kesehatan Dasar pada 2007 sampai dengan Riset Kesehatan Dasar pada $2013 .^{2}$

Dari publikasi di The Lancet Juni 2016 melaporkan bahwa pada tahun 1980 ditemukan 1,225 milyar orang dewasa di dunia sudah menderita kelebihan berat badan dan obesitas. Pada tahun 2011 meningkat menjadi 1,6 milyar orang dewasa mengalami kelebihan berat badan dan 400 juta sudah obesitas. Kemudian pada tahun 2013 menjadi 2,3 milyar orang dengan kelebihan berat badan dan 700 juta sudah obesitas. ${ }^{5}$

Di berbagai negara maju dan berkembang juga memperlihatkan bahwa peningkatan prevalensi obesitas seperti di Amerika Serikat dari tahun 1960-1980 terjadi peningkatan dari 2-9\% menjadi 15\%. Pada dekade 1980-1990 prevalensi obesitas ini meningkat dari $15 \%$ menjadi $20 \%$. Sehingga pada tahun 2000 prevalensi 
obesitas pada orang dewasa sudah menjadi $30 \%$. Bahkan obesitas grade III ( $\mathrm{BMI} \geq 40$ ) meningkat dari 1,3\% pada tahun 1970 menjadi 4,7\% di tahun 2000. Sebanyak $13 \%$ dari total populasi orang obesitas di dunia ada di Amerika Serikat. Akibat meningkatnya populasi obesitas, maka berbagai penyakit kronik degeneratif yang disebabkan oleh obesitas akan meningkat. Diperkirakan sebanyak 400.000 orang per tahun terjadi kematian dini akibat penyakit tersebut. ${ }^{5}$

Di Inggris, peningkatan prevalensi obesitas juga terjadi hampir 2-3 kali lipat dalam kurun waktu 20 tahun. Pada tahun 1980 ditemukan pria dewasa menderita $6 \%$ dan wanita dewasa sebesar 8\%. Di tahun 2000 prevalensi obesitas meningkat menjadi $21 \%$ dari penduduk dewasa di Inggris. Hal yang menarik di Inggris pada tahun terakhir ini prevalensi obesitas pria dan wanita dewasa sudah makin tidak berbeda. $^{5}$

Di Brazil obesitas merupakan epidemi, sehingga mereka tangani sesuai dengan kaidah penyakit yang tingkat statusnya epidemi. Hasil 2 survei dalam 4 tahun terakhir ini ditemukan peningkatan prevalensi kelebihan berat badan dari $43 \%$ menjadi 48\%, sedangkan obesitas meningkat dari $11 \%$ menjadi $15 \%{ }^{5}$

Dalam kurun waktu 20-25 tahun terakhir ini, China merupakan negara yang begitu meningkat perkembangan ekonominya. Di kota besar China sudah terjadi peningkatan prevalensi obesitas mencapai 12,3\% pada orang dewasa. Sebaliknya di Australia sebanyak $28 \%$ pria dan $30 \%$ wanita sudah mengalami obesitas.

Dari hasil penelitian global tahun 2013 yang didukung oleh Bill \& Melinda Gates Foundation yang diterbitkan dalam The Lancet bulan Mei 2014, ditemukan 10 negara dengan jumlah populasi yang menderita obesitas terbanyak di dunia. ${ }^{6}$

Tabel 1. Distribusi negara berdasarkan jumlah penduduk yang menderita obesitas

\begin{tabular}{rlc}
\hline No & \multicolumn{1}{c}{ Negara } & $\begin{array}{c}\text { Jumlah Penduduk } \\
\text { (juta jiwa) }\end{array}$ \\
\hline 1. & Amerika Serikat & 86,9 \\
2. & China & 62 \\
3. & India & 40,4 \\
4. & Rusia & 29,2 \\
5. & Brazil & 26,2 \\
6. & Meksiko & 24,9 \\
7. & Mesir & 21,8 \\
8. & Jerman & 17,1 \\
9. & Pakistan & 16,7 \\
10. & Indonesia & 15,1 \\
\hline
\end{tabular}

Pada Tabel 2 diperlihatkan persentase penduduk beberapa negara baik pria dan wanita yang menderita obesitas di dunia yang dilaporkan oleh organisasi World Obesity pada tahun 2017.

Bila dilihat prevalensi obesitas di Indonesia hasil Riskesdas tahun 2007 dan 2013 cukup jauh berbeda dari penelitian global tahun 2013 (Tabel 3).

Dari kedua hasil Riskesdas 2007 dan 2013 kelihatan ada penurunan prevalensi obesitas secara nasional, namun angka obesitas masih diatas $10 \%$. Propinsi yang cukup tinggi prevalensi obesitasnya adalah Sulawesi Utara, Gorontalo, Kalimantan Timur dan DKI Jakarta. 
Dari data Riskesdas 2013, balita gemuk/obesitas sudah ditemukan sebesar $11,8 \%$, usia 5-12 tahun sebesar $8 \%$ obesitas, usia 13-15 tahun sebesar 2,5\% sudah obesitas dan menurun pada usia 1618 tahun menjadi 1,6\%. Namun setelah dewasa obesitas ini menjadi meningkat kembali. ${ }^{1}$

Tabel 2. Distribusi negara berdasarkan persentase pada pria dan wanita obesitas

\begin{tabular}{rlcc}
\hline No & \multicolumn{1}{c}{ Negara } & Pria (\%) & $\begin{array}{c}\text { Wanita } \\
(\%)\end{array}$ \\
\hline 1. & Qatar & 40 & 40 \\
2. & Kuwait & 32 & 39 \\
3. Amerika & 31 & 35 \\
& Serikat & & \\
4. & Skotlandia & 24 & 26 \\
5. Australia & 28 & 25 \\
6. & Inggris & 28 & 24 \\
7. & Meksiko & 28 & 30 \\
8. & Cekoslovakia & 24 & 19 \\
9. Jerman & 24 & 22 \\
10. & Polandia & 22 & 20 \\
11. & Portugal & 22 & 17 \\
12. Perancis & 16 & 16 \\
13. & Swedia & 15 & 14 \\
14. & Bulgaria & 14 & 17 \\
15. & Afrika Selatan & 12 & 35 \\
16. & Rusia & 10 & 22 \\
17. & Maroko & 7 & 18 \\
18. & Indonesia & 5,7 & 8 \\
\hline
\end{tabular}

Tabel 3. Distribusi Propinsi di Indonesia berdasarkan persentase penderita obesitas

\begin{tabular}{rlcc}
\hline No & \multicolumn{1}{c}{ Negara } & $\begin{array}{c}2007 \\
(\%)\end{array}$ & $\begin{array}{c}2013 \\
(\%)\end{array}$ \\
\hline 1. & Aceh & 14,6 & 16,3 \\
2. & Sumatera Utara & 19,1 & 18,1 \\
3. & Sumatera Barat & 18,2 & 13,5 \\
4. & Riau & 15,4 & 13,7 \\
5. Jambi & 11,9 & 12,3 \\
6. & Sumatera Selatan & 10 & 10,9 \\
7. & Bengkulu & 19,6 & 12,9 \\
8. & Lampung & 13,8 & 8,2 \\
9. & Bangka Belitung & 20,1 & 18 \\
10. & Kepulauan Riau & 19 & 18,2 \\
11. & DKI Jakarta & 27,9 & 20,8 \\
\hline
\end{tabular}

\begin{tabular}{|c|c|c|c|}
\hline 12. & Jawa Barat & 23,1 & 15,2 \\
\hline 13. & Jawa Tengah & 18,4 & 12,8 \\
\hline 14. & DI Yogyakarta & 18,4 & 15,8 \\
\hline 15. & Jawa Timur & 19 & 16,4 \\
\hline 16. & Banten & 19,2 & 13,6 \\
\hline 17. & Bali & 19,3 & 16,4 \\
\hline 18. & NTB & 13,7 & 10,2 \\
\hline 19. & NTT & 14,1 & 6,2 \\
\hline 20. & Kalimantan Barat & 15,8 & 10,4 \\
\hline 21. & Kalimantan Tengah & 16 & 12,2 \\
\hline 22. & Kalimantan Selatan & 17,5 & 14 \\
\hline 23. & Kalimantan Timur & 23,5 & 20,6 \\
\hline 24. & Sulawesi Utara & 31,5 & 24 \\
\hline 25. & Sulawesi Tengah & 22,1 & 16,4 \\
\hline 26. & Sulawesi Selatan & 21,4 & 13,6 \\
\hline 27. & Sulawesi Tenggara & 17,1 & 12,4 \\
\hline 28. & Gorontalo & 27 & 21 \\
\hline 29. & Sulawesi Barat & 15,9 & 10,2 \\
\hline 30. & $\begin{array}{l}\text { Maluku-Maluku } \\
\text { Utara }\end{array}$ & 25 & 18,3 \\
\hline 31. & Papua Barat & 23,1 & 18 \\
\hline & Papua & 27,1 & 15,9 \\
\hline Indo & esia & 18,1 & 14,8 \\
\hline
\end{tabular}

\section{DISTRIBUSI KEJADIAN OBESITAS}

Secara epidemiologi obesitas tidak akan terdistribusi sedemikian rupa saja di tengah masyarakat, akan tetapi obesitas akan terjadi karena ada faktor-faktor yang menyebabkannya seperti: (1) Jenis kelamin, secara empiris wanita lebih banyak menderita obesitas dibanding pria. Hal ini disebabkan faktor hormon wanita dan aktivitas sehari-hari serta persentase lemak tubuh; (2) Usia, meskipun obesitas sudah dimulai sejak kecil sampai menjelang tua. Namun usia yang paling banyak menderita obesitas adalah usia 35-60 tahun. Faktor penyebab obesitas pada usia ini adalah faktor makanan, gaya hidup, aktivitas pekerjaan dan kondisi psikologis; (3) Tingkat pendidikan, dari laporan OECD 2016 ditemukan wanita berpendidikan 
rendah 2-3 kali menderita obesitas lebih banyak dibanding dengan wanita berpendidikan tinggi. Pada pria tidak ditemukan perbedaan yang spesifik tersebut. Apabila anggota keluarganya mengalami obesitas terutama orang tuanya, maka anaknya akan mempunyai peluang lebih besar mengalami obesitas. Terjadinya hal ini oleh karena dampak gaya hidup, pola makan dan kebiasaan olah raga di tingkat rumah tangga; (4) Status ekonomi, di negara maju seperti Amerika serikat, Rusia, Jerman, dan Tiongkok obesitas banyak terjadi pada kelompok

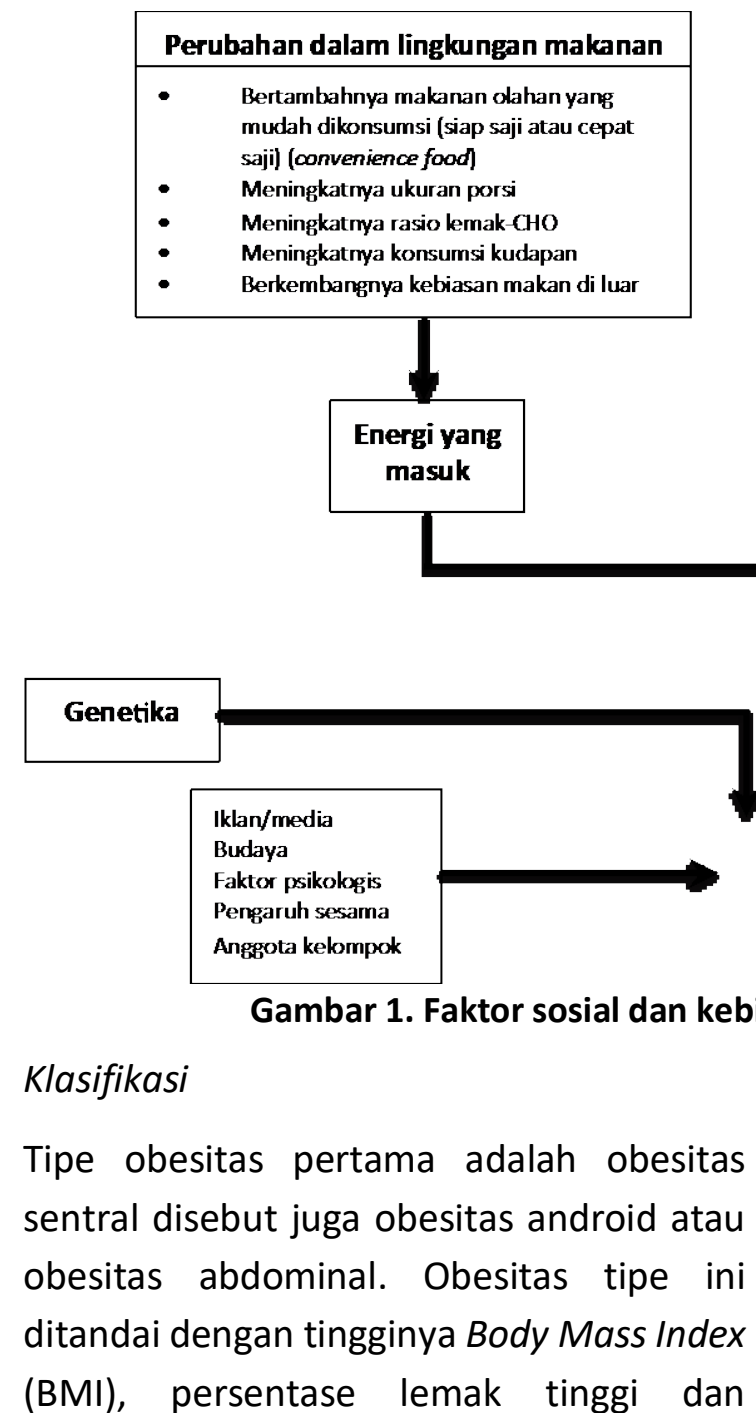

masyarakat dengan sosio-ekonomi menengah dan tinggi. Sedangkan di negara berkembang seperti India, Indonesia, Mesir dan Pakistan kejadian obesitas banyak terdapat pada masyarakat dengan tingkat sosio-ekonomi menengah ke bawah.

\section{Faktor Risiko}

Faktor risiko dasar dari terjadinya obesitas yaitu faktor peningkatan intake, faktor metabolik dan penggunaan kalori dan gen. Kondisi ini terjadi karena modernisasi, globalisasi dan urbanisasi secara spesifik dapat dilihat pada Gambar 1.

Meningkatnya gaya hidup kurang gerak (sedentary lifestyde)

Berkurangrya pekerjaan manual Mekanisasi

Urbanisasi dalam populasi

Game elektronik menggantikan aktivitasi fisk

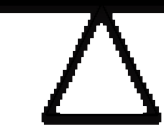

Energi yang keluar

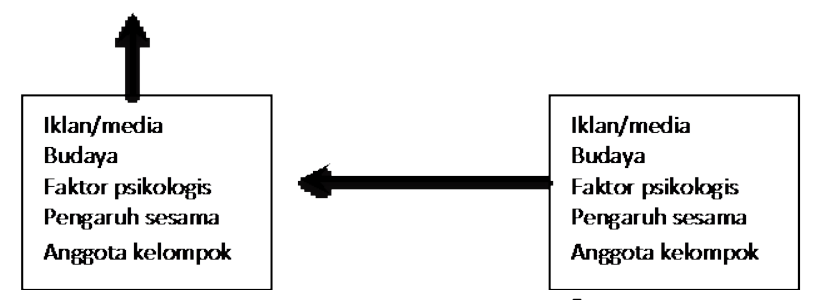

Anggota kekmpok

lingkaran perut juga besar, pria $>94 \mathrm{~cm}$ dan wanita $>80 \mathrm{~cm}$. Penumpukan lemak di daerah visceral. Obesitas tipe sentral merupakan faktor risiko mayor untuk berkembang menjadi diabetes melitus tipe 2. Hal ini dapat dilihat pada Gambar 2. 
Berikutnya adalah obesitas periferal tetapi lingkaran perut normal. disebut juga dengan obesitas ginekoid. Karakteristik dari obesitas ini ditandai Penumpukan lemaknya di subkutaneus dan dengan BMI dan persentase lemak tinggi perifer. Obesitas jenis ini ditemukan pada wanita dan bersifat metabolik proteksi.

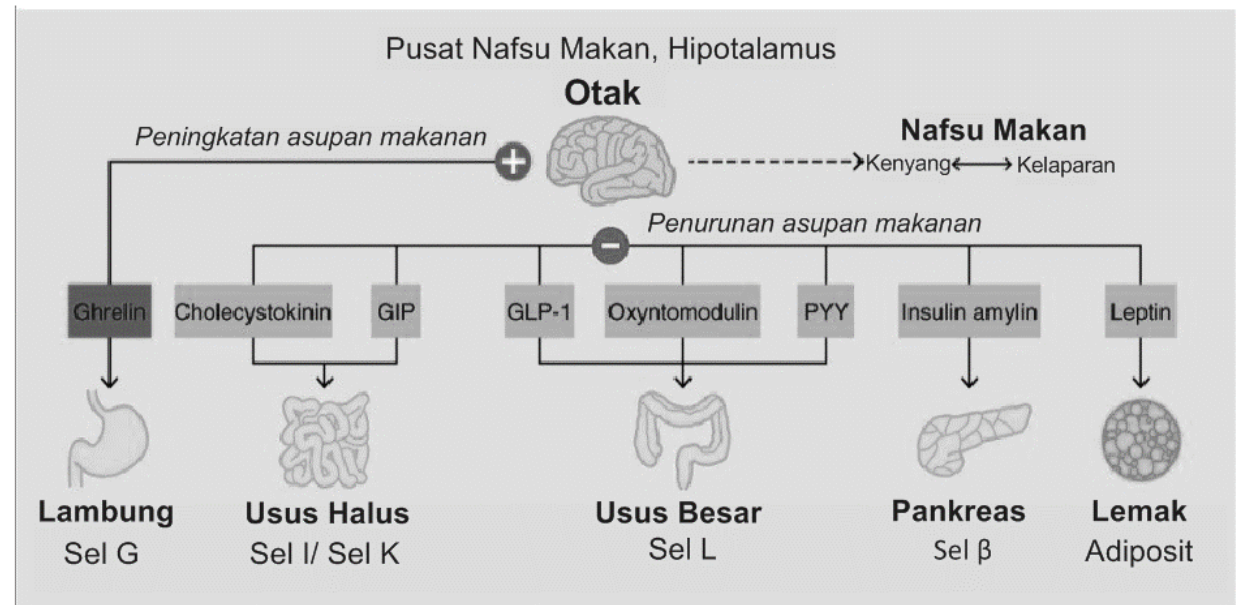

Gambar 2. Peningkatan jalur hubungan jaringan lemak terhadap risiko penyakit kronik.

DAMPAK OBESITAS TERHADAP STATUS KESEHATAN MASYARAKAT

Status kesehatan masyarakat dipengaruhi oleh faktor genetik, perilaku, kesehatan lingkungan dan pelayanan kesehatan. Obesitas suatu kelainan pada dasarnya merupakan aspek perilaku yaitu perilaku mengonsumsi makanan yang kaya energi dan perilaku penggunaan energi. Apabila kedua aspek dasar ini tidak teratasi, maka sulit untuk mengendalikan obesitas di masa datang.

Para ahli epidemiologi sudah membicarakan bahwa pengendalian obesitas ini jauh lebih sulit dari pengendalian rokok dan alkohol. Di samping itu dampak obesitas sangat luas terhadap munculnya berbagai penyakit kronis dan degeneratif. Pada tahun 2015 terdapat 4 juta kematian di dunia yang penyebab awalnya adalah obesitas. Berbagai dampak obesitas terhadap kesehatan masyarakat seperti: Percepatan proses penuaan. Umur biologis adalah usia tubuh yang dipengaruhi oleh kondisi kesehatan secara umum. Salah satu untuk menghitung umur biologis melalui komposisi lemak dalam tubuh. Bila sel lemak berlebih maka dikeluarkannya zat-zat yang bersifat oksidatif atau radikal bebas yang bisa menyebabkan umur sel lebih tua; (2) Gangguan kecerdasan. Studi Human Brain Mapping melaporkan bahwa jaringan otak anak yang obesitas $4 \%$ lebih kurang dari anak dengan berat badan normal. Orang dewasa yang menderita obesitas otaknya 8 tahun kelihatan lebih menua dari orang dewasa dengan berat badan normal. Hal ini disebabkan oleh efek radikal bebas dan gangguan pembuluh darah perifer karena kadar kadar lemak dan gula yang tinggi; (3) Resistensi insulin. Obesitas merupakan faktor risiko munculnya resistensi insulin yang akan 
bermanifestasi munculnya hipertensi, dislipidemia, hiperuremia, disfungsi endotel dan lipotoksisitas terhadap sel beta. Akibat obesitas sentral akan meningkatkan kejadian DM tipe 2, penyakit kardiovaskuler dan gangguan pembekuan darah. Sebesar $60 \%$ penderita DM tipe 2 berhubungan dengan obesitas; (4) Kanker. Walaupun belum kuat bukti ilmiah hubungan sebab akibat obesitas ilmiah hubungan sebab akibat obesitas dengan kanker namun banyak bukti penurunan berat badan dan peningkatan aktivitas fisik dapat bermanfaat untuk mencegah perkembangan sel kanker. Hal ini diduga melalui peranan Insulin-Like Growth Factor (IGF) yaitu terjadinya peningkatan jumlah reseptor ini sehingga sel menjadi lebih reaktif terhadap IGF; (5) Osteoartritis sebagai efek mekanisme akibat obesitas berupa bisa osteoatritis pada sendi, vena verikosa, kesulitan bernafas; (6) Kolelithiasis; (7) Kematian pada usia muda. Oleh karena luasnya dampak dari obesitas pada manusia sehingga angka morbiditas meningkat dan akhirnya angka mortalitas juga meningkat. Laporan OECD tahun 2010, mengungkapkan bahwa orang obesitas 810x lebih cepat risiko meninggal dibanding orang yang tidak obesitas. Setiap kelebihan berat badan $15 \mathrm{~kg}$ dari berat badan ideal maka akan meningkat risiko kematian sebesar $30 \%$.

DAMPAK SOSIAL-EKONOMI DARI OBESITAS

Aspek Sosial

Dari studi pada 200 negara di dunia yang dipublikasi pada The Lancet April 2016 menyebutkan akan terjadi peningkatan prevalensi obesitas global mencapai $18 \%$ untuk pria dan $21 \%$ untuk wanita di tahun 2025. Kondisi ini tentu memicu semakin meningkatnya risiko penyakit degeneratif seperti diabetes melitus tipe 2, kardiovaskular, stroke, kanker dan kelainan muskuloskletal. Kondisi ini tentu akan berdampak terhadap status kesehatan dan ekonomi bangsa serta dunia. ${ }^{4}$

Dampak sosial dari meningkatnya obesitas ini akan menurunnya kualitas kehidupan penderita, menurunnya produktivitas individu dan negara serta tingginya biaya asuransi/biaya kesehatan di suatu negara. Penurunan kualitas kehidupan terjadi pada usia produktif yang diperlukan oleh keluarga, masyarakat dan negara untuk berbagai aktivitas produktif. Salah satu contoh dari obesitas ASEAN yang dilaporkan AROFIIN tahun 2017 yaitu: (1) Filipina menurun tahun produktif sebesar 8-12\%; (2) Malaysia menurun tahun produktifnya sebesar 6-11\%; (3) Indonesia menurun tahun produktifnya sebesar 3-8\%.

Pekerja yang menderita obesitas terjadi penurunan produktivitasnya sebesar $18 \%$. Berbagai dampak sosial akan muncul karena kesakitan dan kematian anggota keluarganya akibat penyakit yang berkaitan dengan obesitas. Berbagai fasilitas umum seperti di tempat sarana umum, transportasi dan kantor akan berubah akibat semakin meningkatnya jumlah penderita obesitas. Bila terjadi peningkatan obesitas dengan penyakit penyertanya di Negara berkembang dan miskin tentu berdampak terhadap meningkatnya 
kemiskinan dan ketidakseimbangan dengan pendapatan keluarga. Pada beberapa negara pekerja gemuk menjadi persoalan di dunia kerja karena menyangkut masalah aspek produktivitas yang mulai rendah dan risiko sakit mulai meningkat sehingga hari bekerja aktif jadi berkurang.

\section{Aspek Ekonomi}

Obesitas mempunyai dampak terhadap peningkatan risiko kesakitan dan kematian. Oleh karena itu biaya kesehatan penderita obesitas $25 \%$ lebih tinggi dari orang dengan berat badan normal (Sossi). Biaya yang dikeluarkan merupakan biaya langsung karena kesakitan dan kematian, dan biaya tidak langsung yang dikeluarkan karena menurunnya produktivitas, sering pekerja absen karena sakit dan biaya lainnya. ${ }^{7}$

Sebagai dampak kesakitan pada penderita obesitas Amerika Serikat pada tahun 2008 mengeluarkan dana untuk obesitas dan penyakit penyertanya (direct cost) sebesar US\$ 147 miliar (5-7\%) dari biaya kesehatan Nasional per tahun sebaliknya negara tetangga Amerika Serikat yaitu Kanada menghabiskan biaya 1,7-2,8\% dari kesehatan Nasional pada tahun 2010, Brazil juga menghabiskan biaya untuk mengatasi obesitas sebesar US\$1,7 miliar dolar (2008). Bila dilihat pada negara Asia seperti Cina, pengeluaran untuk mengatasi obesitas pada tahun 2002 sebesar US\$ 2,74 miliar $(3,7 \%)$ dari total biaya kesehatan tahun 2002, pada tahun 2003 meningkat menjadi US\$ 4,8 miliar. Indonesia pada tahun 2016 menghabiskan 2-4 miliar (8$16 \%)$ dari pengeluaran kesehatan. Malaysia sebesar US\$ 1-2 miliar (10-19\%) dari pengeluaran kesehatan, Singapura sebesar US\$ 400 juta miliar. ${ }^{8}$

Dari studi di atas pengeluaran negara untuk mengatasi dengan penyakit penyertanya menghabiskan biaya sekitar 2-7\% dari pengeluaran kesehatannya. Sebaliknya di Indonesia pengeluaran sebesar 8-16\%. Kondisi ini tentu cukup berat bagi suatu negara dan kecenderungan pengeluaran ini semakin meningkat. Untuk itu WHO mengajak semua negara di dunia melaksanakan berbagai upaya mengatasi obesitas ini. $^{9}$

\section{PENGENDALIAN DAN PENANGANAN EPIDEMI OBESITAS}

Kejadian obesitas sudah terjadi hampir di semua negara, baik negara maju, maupun negara berkembang bahkan di negara miskin. Keadaan ini akan berkonsekuensi terhadap derajat kesehatan masyarakat dan berdampak kepada sosial ekonomi yang cukup besar serta cenderung meningkat. ${ }^{10}$

Untuk itu perlu penanganan terintegrasi dalam mengatasi masalah obesitas. Kegiatan ini meliputi deteksi dini kelebihan berat badan, diagnosa dan pengobatan obesitas.

Pendekatan untuk mengatasi masalah obesitas tentu perlu lebih dahulu dipahami aspek penyebab peningkatan obesitas ini dalam kurun waktu 40 tahun terakhir yang meliputi antara lain: ${ }^{11}$ (1) Aspek Sosial; (2) Aspek Biologi; (3) Aspek Teknologi; (4) Aspek Ekonomi. 
Prinsip dasarnya penanggulangan obesitas adalah intervensi gaya hidup dan terapi medik seperti obat-obatan dan operasi bariatik bila diperlukan. Perubahan gaya hidup lebih ditekankan pada modifikasi perilaku makanan dan aktivitas fisik. Penanganan yang komprehensif bersifat kombinasi berbasis masyarakat telah dikembangkan yang disebut dengan teknik Ensemble Prevenons I'Obesite De Enfants (EPODE).

\section{SIMPULAN}

Obesitas sudah menjadi epidemi baru di dunia sejak 25 tahun terakhir ini. Peningkatan obesitas tersebut disebabkan oleh efek perubahan sosial, biologi, teknologi dan ekonomi. Penyebab dasar obesitas adalah ketidakseimbangan antara kalori yang masuk dengan penggunaan kalori.

Dampak obesitas sangat luas terhadap penyakit yang diawali oleh resistensi insulin seperti diabetes tipe 2, kardiovaskuler, kanker, dan lainnya. Peningkatan prevalensi obesitas global akan meningkat pula mortalitas dan morbiditas di usia relatif muda. Konsekuensi dari epidemi obesitas berdampak terhadap derajat kesehatan masyarakat dan meningkatnya pembiayaan kesehatan untuk menanggulangi obesitas.

Dibutuhkan pengendalian dan penanganan epidemi obesitas dengan pendekatan dalam aspek sosial, biologi, teknologi, dan ekonomi. Perubahan gaya hidup lebih ditekankan pada modifikasi perilaku makanan dan aktivitas fisik.

\section{DAFTAR PUSTAKA}

1. Human Development Reports. Global 2016 Human Development Report. New York: United Nations Development Programme; 2016.

2. Kementrian Kesehatan. Riskesdas Dalam Angka Tahun 2013. Jakarta: Kementerian Kesehatan Rl; 2014.

3. Ezzati M, Riboli E. Behavior and Dietary Risk Factor for NonCommunicable Diseases. N Eng J Med. 2013; 369: 954-964. doi: 10.1056/NEJMra1203528.

4. Siedel JC, Vischer TL. Obesitas sebagai determinan mortalitas dan morbiditas. Dalam: Gibney MJ, Margett BM, Kearney JM, Arab L. Gizi Kesehatan Masyarakat. Jakarta: EGC; 2009. Hal.203-215.

5. NCD Risk Factor Collaboration (NCD-RisC). Trend in Adult Body-Mass Index in 2010 Countries from 1975-2014: A Poolid Analysis of 1698 Population-Based Mearsuarement Studies with 19,2 million Participants. Lancet. 2016; 387(10026):1377-1396. DOI: 10.1016/S0140-6736(16)30054-X.

6. Ng M, Fleming T, Robinson M, Thomson B, Graetz N, Margono C, et al. Global, regional, and national prevalence of overweight and obesity in children and adults during 1980-2013: a systematic analysis for the Global Burden of Disease Study 2013. Lancet. 2014; 384(9945):766781.

7. Gozales H. Managing Patient with Obesity. ADIS; 2016. Hal.1-84. doi: 10.1007/978-3-319-12331$\underline{8}$. 
8. Runge CF. Economic Consequences of Obesity. Diabetes. 2007; 56(11):2668-2672. doi: $10.2337 / \mathrm{db07}-0633$.

9. Finkelstein EA, Ruhm CJ, Kosa KM. Economic Causes and Consequences of of Obesity. Ann Rev Public Health. 2005; 26:239-257. doi: 10.1146/annurev. publhealth.26.021304.144628.

10. Avenell A, Brown J, Brow TJ, Poobalan A, Aucott L, Stearns SC, et al. Systematic review of the longterm consequences of treatment for obesity and implications for health improvement. Health Technol Assess. 2004; 8(21):iii-iv.

11. Heymsfield SB, Wadden TA. Mechanisms, Phatophysiology and Management of Obesity. N Engl J Med. 2017; 376:254-266. doi: 10.1056/NEJMra1514009. 